Agustus 2006, Vol. 2, No. 3

Jurnal Penyuluhan

Serial Kepemimpinan

\title{
BEREKSPERIMEN DAN MENGAMBIL RESIKO: \\ Belajar dari Kesalahan dan Kesuksesan
}

Oleh: Dwi Sadono, Bambang Uripno dan Erwiantono

"Ketika orang tidak membuat kesalahan, saya sebagai pemimpin tidak terlalu puas karena itu berarti mereka tidak berusaha dengan keras dan tidak tumbuh"

(Dikutip dari Frank J. Ruck)

\section{Disarikan dari Buku: "The Leadership Challenge", oleh James M. Kouzes dan Barry Z. Posner. 1991. Jossey-Bass Publisher, Oxford.}

Proses mencari peluang keluar dari tradisi adalah sebuah pencarian sesuatu yang baru. Hal ini memerlukan kreativitas dari seseorang dan pengorganisasian inovasi. Hal itu berarti bahwa pemimpin harus memiliki sikap terbuka terhadap ide-ide dan kemauan mendengarkan, mencoba pendekatan yang belum teruji, dan menerima resiko.

Dalam bab ini mengungkap sumber ide baru, pentingnya komunikasi yang terbuka, bagaimana sikap yang benar dapat merubah sesuatu yang sulit menjadi peluang yang dapat dipelajari. Tetapi hal pertama yang harus dipelajari adalah memecahkan masalah dalam the nine dot problem. Dalam suatu workshop kepemimpinan Apple Computer, John Sculley menggambar 9 (sembilan) titik dalam tiga dalam tiga baris dan tiga kolom dengan jarak yang sama, dan meminta peserta untuk menghubungkan semua titik-titik tersebut dengan empat garis lurus bersambung. Ini adalah permainan dari kotak imajiner. Kesalahan dalam menarik garis membuat masalah tidak terpecahkan, yang diakibatkan karena kita tidak keluar dari kotak imajiner, rutin, dan membebaskan pikiran keluar dari asumsi atau batasan yang dibuat untuk dirinya sendiri. Demikian pula dalam dunia bisnis. Hanya dengan membebaskan diri dari hal yang rutin, dapat membuat manajer dapat bergerak ke sesuatu yang baru, yang lebih menguntungkan. Ini adalah salah satu tes kreativitas diri.

Hal tersebut menggambarkan bagaimana pemimpin dapat turun tangan pada langkah yang tidak biasanya untuk membawa organisasi ke dalam pengaturan yang baru. Kadangkadang pemimpin harus membawa dirinya untuk memecahkan kondisi yang ada kepada kreativitas. Sebagai contoh yang dilakukan J. Telnack, chief design executive Ford Motor Company. la meminta para desainer untuk mengidentifikasi semua hal yang mengganggu proses, dibantu oleh konsultan luar. Hasilnya, dapat ditingkatkan efektivitas dan efisiensi, dan memperoleh penghargaan Motor Trend Car of the Year. The nine dot problem adalah kiasan dari ketidakleluasaan diri dari peraturan, rutinitas dan asumsi. SOP (standard operasional procedure) adalah kebiasaan 


\section{Jurnal Penyuluhan}

organisasi yang dapat berpotensi menjadi penghalang ketika inovasi diperlukan. Solusi kreatif untuk masalah bisnis yang sulit diperlukan identifikasi atau, lebih baik, menghindari pembatasan diri. Kita perlu melihat kondisi luar jika ingin inovatif. Inovasi penting untuk kesehatan organisasi. Tanpa inovasi yang terus dari produk, pelayanan, dan proses kerja, organisasi akan terhenti pertumbuhannya. Inovasi adalah 'makanan' bagi pengembangan organisasi.

\section{Pelajaran dari Inovasi: Komunikasi}

Saluran komunikasi yang terbuka adalah prasyarat agar produk, proses, dan pelayanan yang baru menyebar dalam organisasi. Jaringan komunikasi adalah vena dan arteri ide baru. Pemimpin dapat mengharapkan keinginan berubah yang datang dalam maupun luar organisasi. Pelanggan adalah sumber permintaan inovasi produk dan pelayanan. Jika pemimpin mulai mendeteksi keperluan untuk perubahan, mereka harus menggunakan "penglihatan luar"nya, selalu sensitif terhadap kejadian di luar, jalan ke luar atau bertanya pada konstituen, pelanggan, pekerja, stakeholder, vendor, penguasa, atau hanya keinginan partai. Mereka harus mendengarkan dan tetap berhubungan.

Komunikasi Eksternal dan Internal. J.M. Utterback dari MIT yang mendalami inovasi menemukan bahwa untuk menjadi kekuatan pasar utama dipengaruhi oleh inovasi. Peneliti lain juga memperkuat kesimpulannya. M. Maidique dari University of Miami dan B.J.
Zirger dari Stanford University mempelajari pengenalan produk-produk baru elektronik. Faktor yang menjadi kunci sukses adalah mengembangkan interaksi tim dengan pelanggan. Baik komunikasi eksternal maupun internal sama-sama memegang kunci penting. R. Katz dan T. Allen dari MIT Sloan School memberikan tambahan fakta bahwa kelompok pekerja yang diisolasi dalam jangka waktu cukup lama (lebih dari 5 tahun) dari dunia luar, menunjukkan performans teknik yang rendah dan sebaliknya untuk pekerja yang tidak diisolasi dari dunia luar. Untuk memasukkan ide baru ke dalam organisasi, pemimpin perlu membangkitkan semangatnya secara periodik. Hal ini dapat dilakukan dengan memasukkan anggota baru, melakukan perjalanan keluar, atau bergabung dalam seminar. Apapun tekniknya, pemimpin harus tetap siaga untuk memperkuat arteri komunikasi.

Melihat Keluar dan ke Dalam. Melihat keluar merupakan kekuatan merasakan dunia luar dan untuk itu diperlukan keterbukaan, Pemimpin harus menghilangkan penghalang agar dapat mendeteksi perubahan. Pemimpin harus membuka mata dan telinga, memberikan layanan, membuka argumen, dan mengijinkan ide baru masuk ke dalam organisasinya. Inovasi memerlukan banyak mendengar dan komunikasi daripada mengerjakan hal-hal yang rutin. Ketika mengawal suatu perubahan, pemimpin tetap harus menjaga relasi, berhubungan dengan berbagai sumber informasi, dan berkeliling lebih banyak. Hanya melalui kontak manusia, perubahan dan inovasi 
Agustus 2006, Vol. 2, No. 3

Jurnal Penyuluhan

dapat mencapai efektivitas.

\section{Pentingnya Mengambil Resiko}

Resiko bersifat inheren dalam setiap kesuksesan inovasi. Jika ingin meningkatkan organisasi, maka harus berani mengambil resiko. Iklim kerja untuk sukses dicirikan oleh dua hal: (1) sistem imbalan yang pantas atas keberhasilan, dan (2) kemauan mengambil resiko dan bereksperimen dengan ide inovasi. Satu hal penting yang membedakan pemimpin dari birokrat adalah bahwa pemimpin mendukung pengambilan resiko, mendorong orang lain untuk melangkah ke dalam ketidaktahuan daripada selalu bermain aman. Adalah tidak mudah untuk menentukan tingkat penerimaan resiko. Bagi seseorang adalah resiko, sementara bagi orang lain adalah aktivitas yang bersifat rutin. Kita perlu mengukurnya sendiri tingkat resiko tersebut. Namun pemimpin perlu mengetahui keahlian dan motivasi para pengikutnya. Pemimpin menetapkan tujuan yang lebih tinggi dari sekarang tetapi tidak terlalu tinggi karena hanya akan mengakibatkan orang lain merasa frustasi. Para pemimpin menaikkan level/standar secara bertahap dan menawarkan pelatihan untuk membangun keahlian yang dapat membantu orang melampaui setiap tingkat baru.

\section{Resiko sebagai Pengganggu Hambatan Diri.}

R. Taini dan R. DuBois melalui organisasinya membuat program pengembang eksekutif yang melibatkan, satu diantara bermacam hal, tantangan di luar ruangan yang disebutnya sebagai the Wilderness School. Melalui program ini, dikenal orang dengan jieldtrips, para partisipan mempelajari tentang kepercayaan, pengambilan resiko, pemecahan masalah dalam kelompok, dan kerja tim. Taini, ahli biologi lapangan, bereksperimen dengan petualangan lapangan (pendakian, arung jeram, menyediakan makanan untuk orang tua, mengunjungi daerah miskin dan membersihkan sampah di kota, dan lain-lain) untuk anak sekolah menengah.

Dengan menggandeng DuBois, ahli rekreasi, program diperluas untuk berbagai kalangan dan dikembangkan kursus tali-temali di La Honda, California di lahan seluas 5 ha. Mereka juga menggandeng para veteran perang berkursi roda, imigran turunan Vietnam, dan lain-lain. Program ini telah melatih lebih dari 75.000 orang. Mereka mendorong orang untuk melakukan hal-hal yang umumnya belum pernah dilakukan, untuk bereksperimen dengan diri sendiri, untuk merentangkan dan melewati batasan yang dibuat oleh diri sendiri. Sebagai contoh, berjalan di atas kabel yang direntangkan pada ketinggian 35 kaki. Satu pelajaran yang muncul adalah rasa takut dan kekhawatiran merupakan halangan yang paling besar untuk meraih kesuksesan dibandingkan dengan kesulitan atau bahaya nyata dari eksperimen itu sendiri. Kunci suksesnya adalah membawa orang melampaui batasan-batasan yang biasanya mereka tetapkan untuk diri mereka sendiri.

\section{Mendorong Orang untuk Beresiko Gagal.}


Resiko yang dapat terjadi pada kursus tali temali serupa dengan resiko yang harus dihadapi para pemimpin ketika harusbelajar dan menguasai perubahan: melakukan kesalahan atau lebih buruk lagi, gagal. Berbagai penelitian menunjukkan pentingnya kesalahan dan kegagalan untuk kesusksesan seseorang. Kualitas kerja akan meningkat ketika orang memiliki kemungkinan untuk gagal. Para pesohor dunia seperti T.A. Edison dan lain-lain juga mengalami kegagalan sebelum akhimya mencapai kesuksesan yang gemilang. Ketika belajar sesuatu yang baru kemungkinannya adalah kita tidak pernah menguasainya dengan baik pada hari pertama. Kemungkinan ada kegagalan dan melalui kegagalan kita belajar sesuatu yang baru. Hal ini seperti ungkapan pelatih ski: "jika anda tidak jatuh, anda tidak belajar".

Hal ini bukan berarti untuk mempromosikan kegagalan atas nama kegagalan itu sendiri dan kegagalan bukan menjadi tujuan dari setiap usaha. Sebaliknya, dalam hal ini adalah disarankan pembelajaran. Belajar tidak akan terjadi tanpa adanya kesalahan. Ini disebut sebagai trial and error. Seperti halnya resiko, tidak ada tes sederhana untuk menentukan taktik terbaik dalam belajar.

Hal yang paling sehat adalah menentukan apakah sesuatu yang dipelajari layak dengan biaya yang dikeluarkan. Ternyata bahwa kemampuan berkembang dan belajar amat tergantung pada bagaimana melihat dan mengartikan perubahan. Kita perlu mengukurnya sendiri tingkat resiko tersebut. Namun pemimpin perlu mengetahui keahlian dan motivasi para pengikutnya. Pemimpin menetapkan tujuan yang lebih tinggi dari sekarang tetapi tidak terlalu tinggi karena hanya akan mengakibatkan orang lain merasa frustasi. Para pemimpin menaikkan standar secara bertahap dan menawarkan pelatihan untuk membangun keahlian yang dapat membantu orang melampaui setiap tingkat baru.

\section{Faktor Ketahanan: Bertahan dari Stres Akibat Perubahan}

Ketidakpastian, resiko, dan kesalahan adalah bagian dari harga yang harus dibayar dari inovasi. Bagaimana kita belajar menerima kegagalan dan tekanan yang ditimbulkan dari inovasi? Sebagian besar orang mempersepsikan tekanan/stres dengan sakit. Padahal stres bahkan dalam keadaan yang parah — tidak akan mengakibatkan sakit parah. Bukan tekanan yang membuat kita sakit, melainkan bagaimana kita merespon kejadian yang penuh tekanan. Pengalaman pribadi terbaik dari para pemimpin dalam proyek yangsulit, tekanan dari pekerjaan melahirkan entusiasme dan kenikmatan.

\section{Dekati Stres secara Positif.}

Para psikolog mengakui bahwa individu mempunyai sikap yang berbeda dalam menghadapi stres. Ada individu dengan stres berat/sakit berat dan stres berat/sakit ringan. Perbedaan ini disebut sebagai kekuatan psikologis. Para eksekutif dengan stres berat/ sakit ringan, memiliki: komitmen kuat, 
Agustus 2006, Vol. 2, No. 3

\section{Jurnal Penyuluhan}

kemampuan pengendalian diri, dan kemampuan menghadapi tantangan. Sebaliknya pemimpin yang tinggi stres/penyakit berat merasa terasing, kehilangan kekuasaan, dan melihat perubahan lebih sebagai hambatan daripada tantangan. Orang dengan pribadi yang kuat memanfaatkan tekanan dalam hidupnya dengan langkah dan arah yang pasti. Ketika menghadapi tekanan -positif atau negatifmereka akan: (1) mempertimbangkan dimana mereka terlibat, (2) merasa bahwa mereka dapat mempengaruhi hasilnya, dan (3) melihat peluang untuk berkembang.

\section{Melahirkan Kekuatan.}

Bagaimana mengembangkan sifat kekuatan? Apakah terkait dengan gen, lingkungan tempat tinggal? Dapat dipelajari di sekolah? Ternyata lingkungan keluarga adalah tempat terpenting dalam melahirkan kekuatan sikap. Ketika lingkungan beragam, banyak tugas yang melibatkan kesuklitan dan dukungan keluarga, maka kekuatan akan berkembang tanpa memandang latar belakang sosial ekonomi. Para pemimpin dapat membantu pengikut mereka beradaptasi secara lebih efektif dengan menciptakan sebuah iklim yang mengembangkan kekuatan, dengan: (1) kemampuan pengendalian dengan memilih tugas yang menantang, (2) membangun komitmen dengan memberikan penghargaan lebih sering, dan (3) mendorong suatu sikap orang untuk melihat perubahan sebagai suatu kemungkinan. Untuk dapat melakukan hal tersebut, maka pemimpin harus: (1) memiliki kekuatan psikologis, dan (2) menciptakan atmosfer yang memberikan kekuatan psikologis para pengikutnya.

\section{Mengatasi Masa Ketidakpastian}

Kekuatan adalah prasyarat untuk menguasai resiko dan tantanngan perabahan. Pemimpin dan anggota memerlukan kepribadian yang kuat karena ada dalam ambiguitas yang tinggi, untuk dapat mengatasi resiko dan kesalahan dari inovasi. Pemimpin perlu mempunyai kompetensi untuk mengawal pengikutnya melalui 'pusaran air' - kemampuan untuk membuat keputusan di bawah kondisi ketidakpastian yang tinggi. Pemimpin tidak hanya ahli perubahan, tetapi juga harus ahli tentang ketidak-pastian. Ketidak-pastian menjadi sumber perlunya kepemimpinan, untuk mengambil keputusan terbaik mengatasi masalah. Pemimpin harus menciptakan iklim organisasi agar anggota dapat menerima tantangan perabahan, mengawal dan menghubungkan gerakan ke arah tujuan akhir. Ketika terlihat menjadi terpisah/menjauh, pemimpin harus menunjukkan kepada kita dunia baru dapat kita ciptakan sedikit demi sedikit atau bagian demi bagian. Keluar dari ketidak-pastian dan kekecauan perubahan, pemimpin bangkit dan mengartikulasikan dunia bara masa depan yang menarik bagi organisasinya.

Komitmen Nomor 2: Lakukan Eksperimen, Ambil Resiko, dan Belajar dari Kesalahan 
Para pemimpin adalah pembuat eksperimen dengan pendekatan bara terhadap suatu masalah. Tugas besar pemimpin adalah pengidentifikasian dan penghilangan batasanbatasan diri serta peraturan organisasi yang menghalangi inovasi dan kreativitas, keluar dari rutinitas, menghadapi resiko, dan mendukung fleksibilitas. Inovasi dan perubahan selalu mengandung tekanan. Dengan sikap yang kuat, pemimpin dapat membawa tuntutan perubahan dan membawanya menjadi suatu tantangan. Ada banyak cara untuk menciptakan iklim yang mendukung pengikut tertantang untuk bereksperimen, mengambil resiko, dan belajar dari kesalahan.

Pertama, pelembagaan proses untuk mengumpulkan ide inovasi. Komunikasi baik internal maupun eksternal adalah penting dalam inovasi. Proses mengumpulkan pendapat banyak caranya: fokus grap, kunjungan, box saran, evaluasi dari pelanggan, kunjungan ke pesaing, dan lain-lain. Masing-masing adalah jalan untuk membuka mata dan telinga untuk melihat dunia luar dan yang menjadi penghalang organisasi. Cara lain adalah dengan 'cermin organisasi', dengan mengundang pihak luar untuk berdiskusi dan memberikan feedback terhadap organisasi seperti yang dilakukan J. Telnack.

Kedua, ambil kumpulan ide dalam agendamu. Apapun metoda yang digunakan, kita harus membuat kumpulan ide menjadi prioritas pribadi. Gunakan kesempatan dalam pertemuan untuk mengemukakan gagasan perubahan, undang staf departemen lain untuk memberi tanggapan bagaimana unit telah berubah, undang pelanggan dalam pertemuan staf.

Ketiga, rancang eksperimen kecil. Jika tidak ada kepastian mengenai efek sebuah ide baru, buatlah eksperimen terlebih dahulu. Evaluasi proses inovasinya: tetapkan cara menilai hasilnya, pembanding, ekperimen ulang, dan lihat hasilnya. T. Peters dan B. Waterman menyatakan: Lakukan. Tetapkan. Coba'.

Empat, perbaharui tim. Tim yang terbaik juga akan bosan setelah berlalunya waktu: mengikuti siklus kehidupan, hanya mengerjakan produksi. Tim perlu penyegaran dengan mengikuti konferensi, training, dan mengunjungi kolega di bagian lain, rotasi.

Kelima, hargai pengambil resiko. Tempatkan di bagian tempat yang banyak dikunjungi tropi, piagam, foto, dan perlengkapan inovasi agar dapat dilihat orang lain.

Keenam, analisis setiap kesalahan, seperti halnya setiap kesuksesan. Banyak pelajaran penting yang dapat dipelajari dari kegagalan. Mengapa tidak melakukannya dengan baik? Apakah sudah belajar dari kesalahan? Dari sisi dapat ditentukan bagaimana dapat melakukan yang terbaik di masa mendatang.

Ketujuh, model pengambilan resiko. Dorong orang lain untuk ikut mengambil resiko dengan mengerjakannya sendiri. Outbound memberikan pelajaran tentang pengambilan resiko, kerjasama tim, dan kepercayaan.

Kedelapan, membentuk kekuatan. Pemimpin dan timnya memperoleh manfaat 
Agustus 2006, Vol. 2, No. 3

dari bekerja dalam iklim kekuatan psikologis, khususnya selama waktu terjadi tekanan berubah. Pemimpin harus membentuk komitmen, kontrol, dan tantangan jika ingin melibatkan partisipasi yang memadai dari pengikutnya dalam melakukan perubahan yang membawa efek terhadap pekerjaannya. 